\title{
AN ILLUSTRATED KEY TO ADULT MALES OF NEOTROPICAL Fannia ROBINEAU-DESVOIDY BELONGING TO Pusio SUB-GROUP (DIPTERA, FANNIIDAE)
}

\author{
COURI, M. S. \\ Departamento de Entomologia, Museu Nacional, Quinta da Boa Vista, CEP 20940-040, Rio de Janeiro, RJ, Brazil \\ Research fellow of Conselho Nacional de Desenvolvimento Científico e Tecnológico, CNPq \\ Correspondence to: Márcia S. Couri, Museu Nacional, Quinta da Boa Vista, \\ CEP 20940-040, Rio de Janeiro, RJ, Brazil, e-mail: mcouri@attglobal.net \\ Received June 27, 2003 - Accepted October 4, 2004 - Distributed November 30, 2005
}

(With 15 figures)

\begin{abstract}
The 11 neotropical species of Fannia belonging to the pusio sub-group (canicularis group), are keyed F. dodgei Seago; F. femoralis (Stein); F. pamplonae Couri \& Araújo; F. parafemoralis Araújo \& Couri; F. paraisensis Araújo \& Couri; F. punctivervis Malloch; F. pusio (Wiedemann); F. sabroskyi Seago; F. snyderi Seago; F. trimaculata (Stein); F. trimaculatoides Couri \& Pamplona. The key is addressed only to the males and the illustrations help in the visualization of the characters.
\end{abstract}

Keywords: Fanniidae, Fannia, key to males, pusio sub-group, identification.

\section{RESUMO}

\section{Chave ilustrada para machos adultos de Fannia Robineau-Desvoidy neotropicais pertencentes ao subgrupo pusio (Diptera, Fanniidae)}

As onze espécies neotropicais de Fannia pertencentes ao subgrupo pusio (grupo canicularis), são chaveadas - F. dodgei Seago; F. femoralis (Stein); F. pamplonae Couri \& Araújo; F. parafemoralis Araújo \& Couri; F. paraisensis Araújo \& Couri; F. punctivervis Malloch; F. pusio (Wiedemann); F. sabroskyi Seago; F. snyderi Seago; F. trimaculata (Stein); F. trimaculatoides Couri \& Pamplona. A chave é direcionada apenas para os machos e as ilustrações auxiliam na visualização dos caracteres.

Palavras-chave: Fanniidae, Fannia, chave para machos, subgrupo pusio, identificação.

\section{INTRODUCTION}

Fannia Robineau-Desvoidy, 1830 (Diptera, Fanniidae) is known in the tropics for 65 valid species.

Mainly based on male terminalia characters, Hennig (1955) and Chillcott (1960) proposed the organization of the Fannia species into groups, some of them divided into sub-groups. Albuquerque et al. (1981) recognized some of these groups to the neotropical species, and also gave a characterization of them.

The pusio sub-group is very homogeneous and belongs to the canicularis group, which can be characterized by the bare parafacial; presence of posteroventral setae on hind coxa; cercal plate longer than wider; surstylus extending from the inner margin of the ninth tergum and absence of a bacilliform processes, while the sub-group pusio can be characterized by the absence of the upper orbital bristle and by the trimaculate abdomen in males (Hennig, 1955; Chillcott, 1960; Albuquerque et al., 1981). Both canicularis group and pusio subgroup can be easily identified in the keys to groups and sub-groups presented by Chillcott (op. cit.) and Albuquerque et al. (op. cit.).

The identification of Fannia males becomes easier as they exhibit a variety of secondary sexual characters, while the females remain relatively primitive (Chillcott, 1960). Among others male diagnostic characters, the bristling especially of the mid and hind femora is particularly important. 
Because of the difficulty of identifying females, the present key is addressed only to the males. The use of the key is facilitated by the illustrations of legs, especially of the hind femur.

Carvalho et al. (1993) lists 9 Fannia species to the pusio sub-group. Araújo \& Couri (1996) added two new species to them.

The present key was based on Seago (1954) and Albuquerque et al. (1981) and includes the 11 neotropical species described to the sub-group: F. dodgei Seago, 1954; F. femoralis (Stein, 1898); F. pamplonae Couri \& Araújo, 1989; F. parafemoralis Araújo \& Couri, 1996; F. paraisensis Araújo \& Couri, 1996; F. punctivervis Malloch, 1934; F. pusio (Wiedemann, 1830); F. sabroskyi Seago, 1954; F. snyderi Seago, 1954; F. trimaculata (Stein, 1898); F. trimaculatoides Couri \& Pamplona, 1990.

\section{ILLUSTRATED KEY TO THE NEOTROPICAL MALE Fannia SPECIES BELONGING TO Pusio SUB-GROUP}

1. Hind femur with a distinct pre-apical ventral swelling (Fig. 1). 2 Hind femur with no pre-apical ventral swelling (Fig. 2 )

2. Hind tibia with long and fine bristles on middle third (Fig. 3) [Mexico, Guatemala, Panama, El Salvador, St. Vicent Is., Guadalupe Is., Puerto Rico, Cuba, Bahamas, Trinidad, Venezuela, Guyana, Brazil, Chile, Galapagos Is., Easter Is., North America, Africa] ...F. pusio (Wiedemann, 1830). Hind tibia without long and fine bristles on middle third...... 3

3. Hind femur on anteroventral surface with a row of close bristles on basal third, beginning post-basally (Fig. 4) and posteroventral surface with a complete row of bristles, longer on apical fourth (Fig. 5) [Panama, Cuba, Colombia, Brazil]

F. dodgei Seago, 1954

Hind femur on anteroventral surface without a row of close bristles on basal third; posteroventral surface without a complete row of bristles, longer on apical fourth; if so, not together with the other above character.

4. Hind femur with a very visible pre-apical protuberance, with many short bristles; anteroventral and posteroventral surfaces bare (Fig. 6) [Brazil, USA] .............................. F. snyderi Seago, 1954 Hind femur with a faint pre-apical protuberance, and not very bristled; anteroventral and posteroventral surfaces with bristles, at least on apical half (Fig. 7).

5. Hind femur on anteroventral surface with 3-4 pre- apical bristles with straight apex distinctly shorter than the corresponding posteroventral (Fig. 7) [Guyana, Brazil] .......... F. sabroskyi Seago, 1954 Hind femur on anteroventral surface with preapical bristles with hooked apex (Fig. 8). . .6

6. Hind femur on anteroventral and/or posteroventral surfaces with a complete row of bristles (Fig. 8) [Brazil (Rio de Janeiro)]

.F. paraisensis Araújo \& Couri, 1996

Hind femur on anteroventral and/or posteroventral surfaces with a bristles at most restricted to apical third. .7

7. Hind femur on anteroventral surface with a row of long bristles on apical third and with more than 4 longer bristles inserted on the swelling; hind tibia on anterodorsal surface with a row of short bristles, the ones on apical third longer (Fig. 9) [Brazil (Rio de Janeiro)]

F. parafemoralis Araújo \& Couri, 1996

Hind femur on anteroventral surface without a row of long bristles on apical third and with 3-4 longer bristles inserted on the swelling; hind tibia on anterodorsal surface with 3 median bristles (Fig. 10) [Mexico, Cuba, Virgin Is., Puerto Rico, Haiti, Dominican Republic, Guyana, Peru, Bolivia, Brazil, Argentina, North America]

.F. femoralis (Stein, 1998)

8. Hind femur on anteroventral surface with only one strong bristle on apical third; anteroventral surface with a row of straight bristles on middle third (Fig. 11) [Belize, Panama, Puerto Rico, Jamaica, Dominican Republic, Haiti, S. Domingo, Ecuador, Peru, Venezuela, Brazil, Uruguay, Argentina] ... 


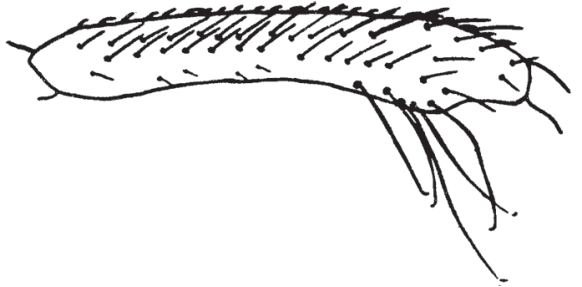

Fig. $1-F$. pusio (Wiedemann). Hind femur, anterior view (modified from Seago, 1954).

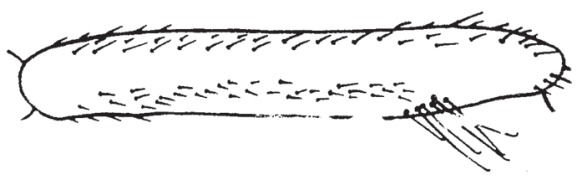

Fig. $2-F$. punctiventris Malloch. Hind femur, posterior view (modified from Seago, 1954).

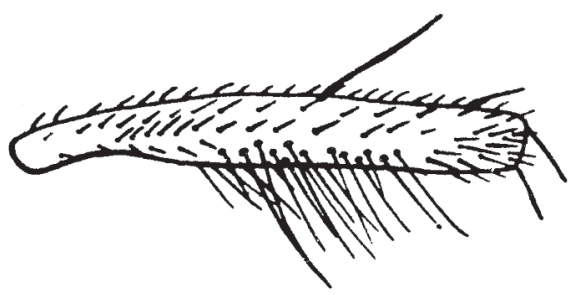

Fig. $3-F$. pusio (Wiedemann). Hind tibia, anterior view (modified from Seago, 1954).

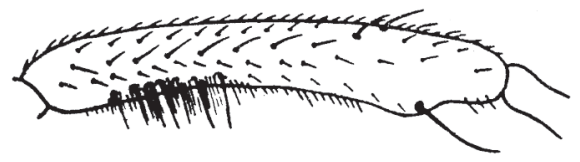

Fig. 4. - F. dodgei Seago. Hind femur, anterior view (modified from Seago, 1954).

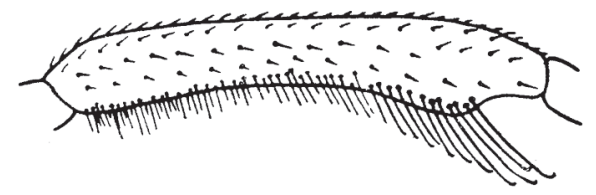

Fig. 5 - F. dodgei Seago.Hind femur, posterior view (modified from Seago, 1954).

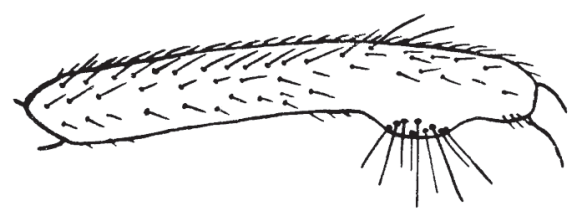

Fig. 6-F. snyderi Seago. Hind femur, anterior view (modified from Seago, 1954).

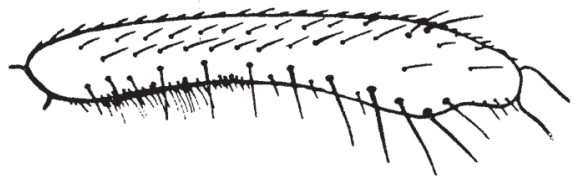

Fig. $7-$ F. sabrosky Seago. Hind femur, anterior view (modified from Seago, 1954).

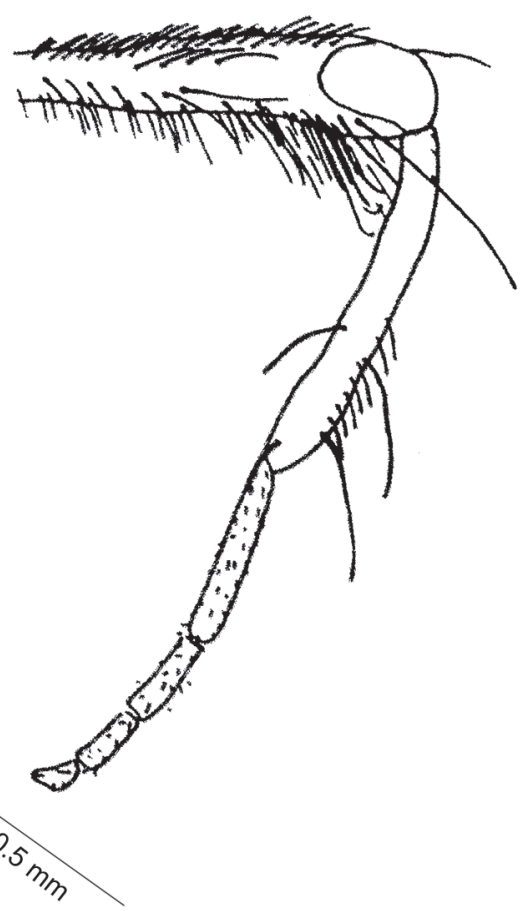

Fig. 8 - F. paraisensis Araújo \& Couri. Hind leg, anterior view (modified from Araújo \& Couri, 1996). 
F. trimaculata (Stein, 1898) Hind femur on anteroventral surface with more than one bristle on apical third; anteroventral surface without a row of straight bristles on middle third (Fig. 12). 9

9. Hind femur on anteroventral surface with 2 bristles on apical third (Fig. 12) [Chile, Juan Fernandez Is.]

F. punctiventris Malloch, 1934

Hind femur on anteroventral surface with many bristles on apical third 10

10. Hind femur on anteroventral surface with a row of similar bristles on basal two-thirds; apical third with long spaced bristles, longer to apex (Fig. 13);

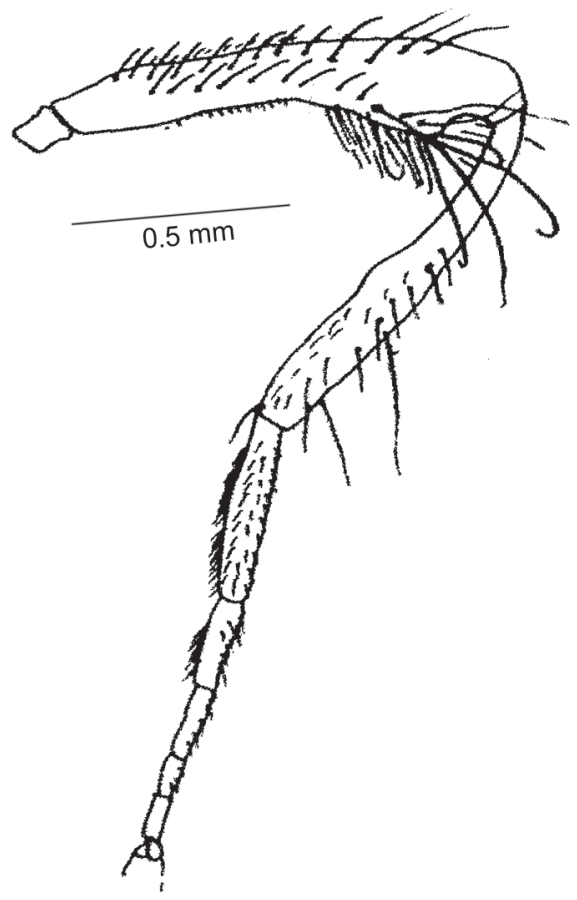

Fig. $9-$ F. parafemoralis Araújo \& Couri. Hind leg, anterior view (modified from Araújo \& Couri, 1996).

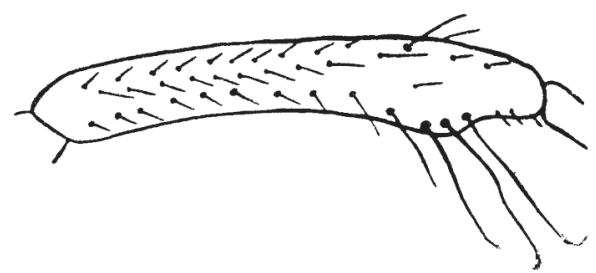

Fig. $10-F$. femoralis (Stein). Hind femur, anterior view (modified from Seago, 1954). mid femur on anteroventral and posteroventral surfaces with short and strong bristles on apical third (Fig. 14) [Brazil (Amazonas)]

.......F. trimaculatoides Couri \& Pamplona, 1990 Hind femur on posteroventral surface with many bristles on basal third not clustered (Fig. 15); mid femur on anteroventral and posteroventral surfaces without short and strong bristles on apical third [Brazil (Rio de Janeiro)]

F. pamplonae Couri \& Araújo, 1989

Acknowledgments - The author is gratified to CNPq for her research grant (process number 300386/80-0) for the financial

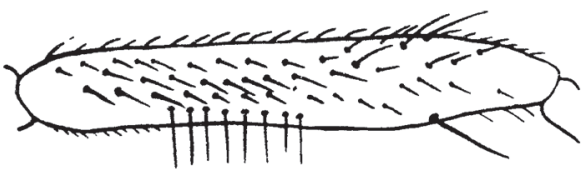

Fig. $11-F$. trimaculata (Stein). Hind femur, anterior view (modified from Seago, 1954).

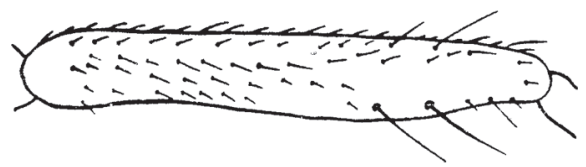

Fig. $12-F$. punctiventris Malloch. Hind femur, anterior view (modified from Seago, 1954).

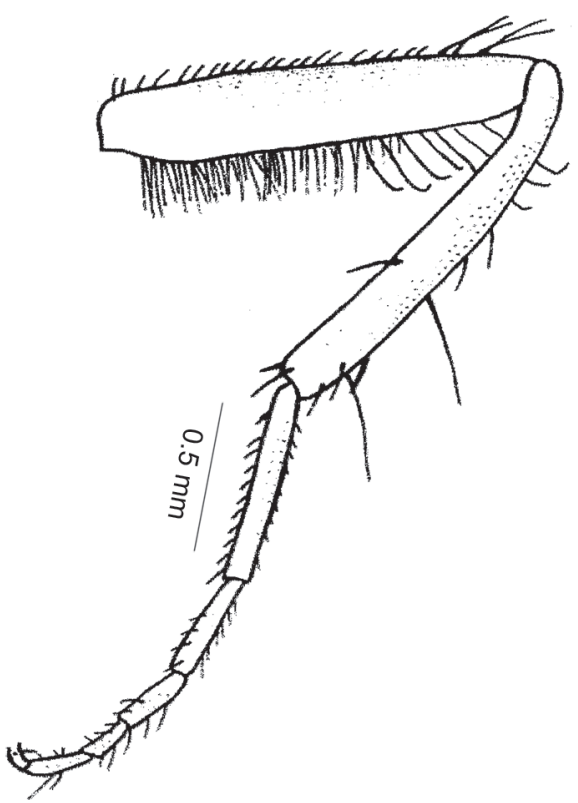

Fig. 13 - F. trimaculatoides Couri \& Pamplona. Hind leg, anterior view (modified from Couri \& Pamplona, 1990). 


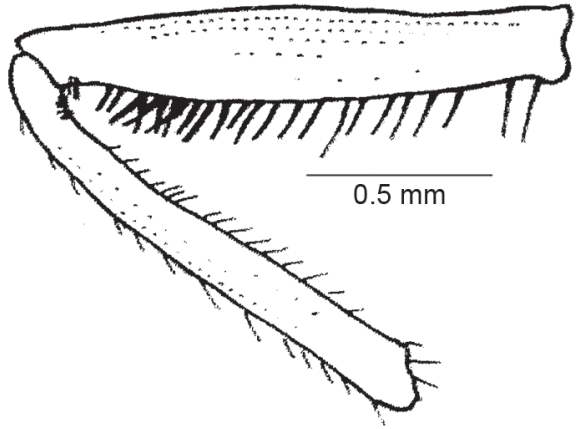

Fig. $14-F$. trimaculatoides Couri \& Pamplona. Mid femur and tibia, posterior view (modified from Couri \& Pamplona, 1990).

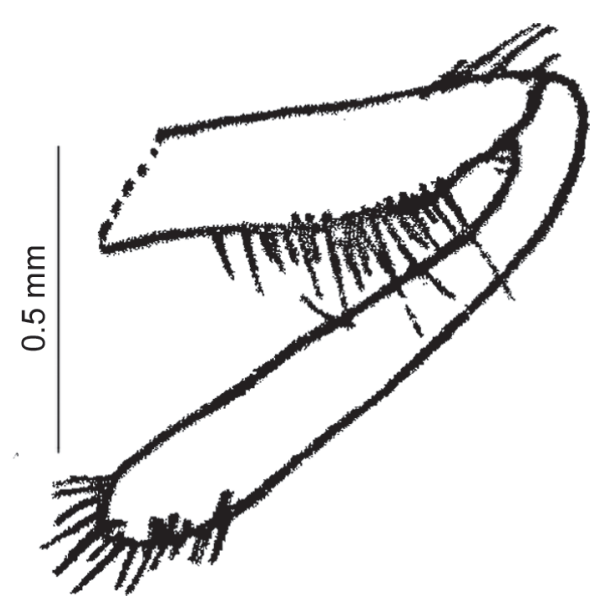

Fig. $15-F$. pamplonae Couri \& Araújo. Hind femur and tibia, posterior view (modified from Couri \& Araújo, 1989). support to the project and to Luiz Antonio Alves da Costa (Museu Nacional) for the final art of the illustrations.

\section{REFERENCES}

ALBUQUERQUE, D. DE O., PAMPLONA, D. \& CARVALHO, C. J. B., 1981, Contribuição ao conhecimento dos Fannia R.-D., 1830 da região neotropical (Diptera, Fanniidae). Archos Mus. nac. Rio de J., Rio de Janeiro, 56: 9-34, 60 figs.

ARAÚJO, P. F. DE \& COURI, M. S., 1996, Duas novas espécies de Fannia Robineau-Desvoidy (Diptera, Fanniidae) do Rio de Janeiro, Brasil. Revta bras. Zool., 13 (2): 335-341.

CARVAlHO, C. J. B.; PONT, A. C.; COURI, M. S. \& PAMPLONA, D., 1993, Parte I. Fanniidae. -I-29 In: A Catalogue of the Fanniidae and Muscidae (Diptera) of the Neotropical region. - Sociedade Brasileira de Entomologia. São Paulo.

CHILlCOTT, J. G., 1960, A Revision of the Nearctic Species of Fanniinae (Diptera: Muscidae). Can. Ent., 92 (14): 295 pp., 289 figs., 1 table, 61 maps.

HENNIG, W., 1955, Muscidae [Part, Lieferung 182]. In: E. Lindner (ed.). Die Fliegen der palaearktischen Region 63 b: 1-48, text figs. 1-16, plates 1-3. Sttutgart.

SEAGO, J. M., 1954, The pusio Group of the Genus Fannia Robineau-Desvoidy, with Descriptions of New Species (Diptera, Muscidae). Amer. Mus. Nov., 1699:13 pp., 20 figs. 